Research Articles

\title{
Chronic Mental Stress Induces Reversible Reduction of Natural Killer Cells and CD56 ${ }^{\mathrm{dim}}$ Subpopulation
}

\author{
${ }^{1,2}$ Manar M. Ismail \\ ${ }^{1}$ Laboratory Medicine Department, Faculty of Applied Medical Science, Umm Al Qura University, KSA \\ ${ }^{2}$ Clinical Pathology Department, National Cancer Institute, Cairo University, Egypt
}

Article history

Received: 12-07-2017

Revised: $12-08-2017$

Accepted: 28-08-2017

Email: manarismail4@yahoo.com

\begin{abstract}
Generally, studying to be a health care provider is a stressful and demanding field and the students have to face many stressors that may affect their general health status including the immune system. This work aimed at studying the effect of prolonged naturalistic life-stress exposure on the percentage of peripheral blood T-lymphocytes and Natural Killer (NK) cells in female laboratory medicine students. 52 peripheral blood samples in the last week of the final written exam (stress time point) and 27 samples after 12 weeks rest (control) were withdrawn and analyzed by flow cytometry. At the stress time point, there was a significant high $\mathrm{T}$ helper cells percentage with elevation of $\mathrm{T}$ helper/ $\mathrm{T}$ cytotoxic ratio, $\mathrm{P}$ value $<0.001$. Also, significant low percentages of $\mathrm{NK}$ cells and CD56 $6^{\mathrm{dim}}$ together with high CD56 ${ }^{\text {bright }}$ subpopoulations were detected, $\mathrm{P}$ value $<0.001$. Lymphocyte analysis of the subgroup that had an attach of common cold $(34.6 \%)$ revealed significant reduction in the number of $\mathrm{T}$ cytotoxic and NK cells, $\mathrm{P}$ values 0.042 and 0.001 respectively. This study concluded that in humans, naturalistic chronic stress as expressed in academic exams has the potential to negatively affect the immune system, but normality is regained after sufficient stress relieve measures. Replication in larger and more diverse sample populations with inclusion of males for comparison is required, Also assessments of NK cell cytotoxicity and T helper cell subsets especially $\mathrm{T}$ regulatory cells are required for future studies.
\end{abstract}

Keywords: Natural Stress, Chronic Stress, Tc Cells, Th Cells, NK Cells, CD $56^{\text {dim }}$ NK Cells

\section{Introduction}

Stress is a pathophysiological process that occurs when an individual is faced with environmental demands that exceed his or her resources. This status will induce physiological and behavioral response to restore homeostasis and meet the demands of the situation. The chronicity of such a situation is potentially pathogenic (Castrillón et al., 2015).

Highlighting the field of medical education, it is a stressful and demanding field with minimal opportunity to relax and recreate. Inability to cope, helplessness, increased psychological pressure, mental tension and too much workload are 'stress factors' for medical students (Lee and Graham, 2001).

Amr et al. (2008) reported that $94.5 \%$ of medical students in Egypt suffer from different stressors. On the same hand, another study done in Pakistan revealed that $94 \%$ of the male medical students consider academics and exams are the most powerful stressors (Shaikh et al., 2004). However, no similar studies included paramedical students who are sharing similar stressors.

The immune system has two arms; the innate and the adaptive branches. The main functions of the innate immune system are rapid destruction of invading pathogens without prior sensitization, inflammatory response and antigen processing and presentation for the $\mathrm{T}$ cells. The adaptive immune system clears residual microorganisms by antibodies and cytotoxic cellular mechanisms and, through immunologic memory, speed up the immune response in future re-exposure (Basset et al., 2003).

The psychoneuroimmunology loop was established after the discovery of the presence of cellular receptors in the nervous, endocrine and immune systems that allows the reception of information via chemical messengers allowing crosstalk between these three systems to establish homeostasis (Nemeroff, 2013; Pittman, 2011). Accordingly, our immune system does 
not operate in isolation and a range of chronic stressors such as bereavement (Phillips et al., 2006), relationship stress (Kiecolt-Glaser et al., 2005) and depression (Zorrilla et al., 2001) have been shown to suppress immune responses.

Some researchers were interested in studying the effect of exam stress on the function and cells of the immune system and performed different study designs based mainly on medical students; normal, atopic, asthmatic or trained to relieve stress. Basically, researchers revealed that the total leukocyte count is not affected by medical exam stress (Fefelova et al., 2015) but most of the studies revealed difference in the lymphocyte subset distribution or neutrophile migration due to change in adhesion molecule expression in chronic stress situation related to academic exams. However no significant difference was observed in lymphocyte subsets in acute pre-exam stress (Marazziti et al., 2007).

In a study done by Naito et al. (2003) they reported small but significant declines in NK cell percentages and cytotoxic activity and an increased $\mathrm{T}$ helper cell. However these changes were buffered in the group of students who learned and practiced self-hypnosis training before exam to relieve stress. In a similar study design, NK cells and T cytotoxic cells were reduced under the effect of exam stress and normalized with self hypnosis training that also increased $\mathrm{T}$ helper cell percentage (Gruzelier et al., 2001).

The Th1/Th2 cytokine balance changes during exam stress were detected in different studies (Peters et al., 2017). The main changes were down-regulation of Th1 (IFN-gamma and IL-2) and a selective up-regulation of Th2(IL-4, IL-5 and IL-6) cytokines (Kang et al., 2001). Skewed Th1/Th2 ratio and reduced NK cell numbers were detected in atopic rather than normal students in association with large exams indicating that atopics may be more strongly affected by stress than others (Höglund et al., 2006; Marshall et al., 2000). Reduction in NK cells was also detected in nursing students in response to academic exam whether healthy or asthmatic (Kang et al., 1988).

\section{Aim of the Study}

Demonstration of the effect of prolonged naturalistic life-stress exposure on the percentage of peripheral blood T-lymphocytes, natural killer (NK) cells and their subsets in female laboratory medicine students.

\section{Subjects and Methods}

This study was conducted at the Faculty of Applied Medical Science, Umm Al-Qura University. The laboratory medicine final exams are held at the end of each semester. The exam period lasts 4 weeks; 2 weeks for practical followed by 2 weeks for final written exams. These exams required at least 4 weeks of focused preparation. Hence, the students are exposed to exam preparation and performance stress over a prolonged period of time i.e. chronic stress.

\section{Study Design}

The female laboratory medicine students who agreed to participate in the study were subjected to analysis twice at two different time points; T1 in the last week of the final written exam and T2 after a 12 week rest and recovery from the stress of the examination period i.e. at the beginning of the next academic year, considering the T2 time point as a control.

A brief medical and social history was taken from the students to fulfill the inclusion and exclusion criteria to obtain a homogenous study sample and avoid biased data analysis.

\section{Inclusion Criteria}

All the study participants had a comparable sociobiological status, they were not pregnant, unmarried and lived with their families, socially active and had sufficient financial support. All the participants were satisfied with their level of academic achievement and they were apparently healthy with normal regular menstrual cycle. None of them received hormonal or endocrinal medications including corticosteroids, estrogen, progesterone or thyroxin and none of them had acute infection at the day of sample withdrawal. Also, sleep disturbance was recorded.

\section{Exclusion Criteria}

This study excluded any participant with chronic disease that necessitates medical attention including obesity, hypertension, Diabetes mellitus, allergic or autoimmune disease or any other endocrinal disorder. Drinking excessive coffee ( $>2$ cups /day), smoking, alcohol consumption or suffering from additional severe life-stress during the exam time (e.g., Death of a family member) were addational exclusion criteria.

This study was approved by the ethical committee of Faculty of Applied Medical Sciences, Umm AL-Qura University and a written informed consent was taken from each participants.

\section{Laboratory Methods}

EDTA peripheral blood was collected from each participant under complete aseptic condition and analyzed on Sysmex 2000 hematological analyzer for total and differential blood count to exclude samples with pathological abnormalities e.g. leukocytosis, leukopenia, lymphocytosis and/or atypical lymphocytes.

Lymphocyte subset identification was performed using BD FACSCalibur System (BD- Bio Science) and reagent system (BD- FACS Setup) using specific fluorochrome conjugated antibodies including: CD3 for 
T lymphocytes, CD16 and CD56 for NK cells, CD4 for helper lymphocytes and CD8 for cytotoxic lymphocytes. Direct staining method was used for sample preparation as previously described (Al-Qouzi et al., 2002). Briefly, $100 \mu \mathrm{l}$ of whole blood was mixed with $20 \mu \mathrm{l}$ of each monoclonal antibody and incubated in the dark at Room Temperature (RT). Red blood cells were then lysed by adding $2 \mathrm{~mL}$ of lysing solution, incubated in the dark at RT for 10 min, then centrifuged and the supernatant was discarded. The pellet was washed with $2 \mathrm{~mL}$ of Phosphate-Buffered Saline (PBS), re-suspended in 500 $\mu l$ of PBS for flow cytometry acquisition. Finally data analyzed with CellQuest software.

\section{Statistical Analysis}

Data were analyzed using SPSS (Statistical Package for Social Sciences; SPSS Inc., Chicago, IL, USA) version 20 for Microsoft windows. Numerical data were presented as mean \pm SD and median (range). Comparisons between two groups were conducted using student $t$ test. Comparison between more than 2 groups was made by using the ANOVA test followed by postHoc comparison test "Tukey test" for paired comparison. Probability $(p$-value $)<0.05$ was considered significant and highly significant if $\mathrm{P}$-value $<0.001$.

\section{Results}

In this work, 79 samples were analyzed; 52 samples at $\mathrm{T} 1$ defined as a study group, their median age was 20 and ranged from 19-27 years. Unfortunately not all the participant could complete the study and we get 27 samples at T2 time point considered as control, their median age was 23 and ranged from 19-25 years.

There was no significant difference between the percentages of $\mathrm{T}$ cells at the two time points, $\mathrm{P}$ value 0.096. However, the $\mathrm{T}$ helper (Th) cells revealed significant high percentages, $\mathrm{P}$ value $<0.001$ and $\mathrm{T}$ cytotoxic (Tc) showed significant low percentages, $\mathrm{P}$ value 0.006 compared to the control group. This variability in the two major $\mathrm{T}$ cell subsets was reflected on the $\mathrm{Th} / \mathrm{Tc}$ ratio where a higher ratio was detected in the study group than the control group, $\mathrm{P}$ value $<0.001$. Data are shown in Table 1.

Regarding NK cells, there was a significant lower percentage in the study group than the control group. On the same hand, the percentage of CD56 $6^{\mathrm{dim}} \mathrm{NK}$ cell population showed significant lower values compared to the control. On the other hand, CD56 ${ }^{\text {bright }} \mathrm{NK}$ cells revealed significant higher percentages in the study group than the control, $\mathrm{P}$ value $<0.001$. Data are shown in Table 2.

Sleep disturbance was reported in 38/52 (61.5\%) participant at T1time point. They suffered from troubles in falling asleep, staying asleep or had irregular sleep schedule. The students who had sleep disturbance did not reveal any significant difference from their colleagues regarding any of the studied parameters, but both groups showed significance with the control group. Data are shown in Table 3.

After sampling at T1 time point, the participant were followed for the development of any signs or symptoms of infection (e.g. Fever, malaise, weakness, headache, rhinorhea, appearance of shingles,...). Eighteen out of 52 $(34.6 \%)$ had a common cold attack during the examination period or shortly after the exam and we noticed that some of them $(8 / 18)$ had shingles around the nose or the mouth. This group showed a significant reduction in the number of $\mathrm{T}$ cytotoxic cells and $\mathrm{NK}$ cells, $P$ value 0.042 and 0.001 respectively compared to the group that did not report signs of infection. Data are shown at Table 4.

\section{Discussion}

Over the past 30 years, psychoneuroimmunology researches documented that various types of stressors can reduce immunity and resistance to diseases (Segerstrom and Miller, 2004) and this effect vary markedly depending upon whether stress is acute or chronic (Matalka, 2003).

In this study, quantitative measurements of $\mathrm{T}$ cells, Th, Tc and NK cells was carried over during a state of mental stress to reveal any deviation from normal values and to check if these changes are revisable after sufficient period of rest. This study included females only as it was previously reported that the stress response and immune response would differ between males and females that may be partly related to the different hormonal profile (Breen et al., 2016).

In the current work, Th cells increased significantly during stress time point together with decrease in the Tc levels leading to significant higher values of $\mathrm{Th} / \mathrm{Tc}$ ratio than the control. Our findings are comparable to many authors who studied the effect of stress on the immune system in different clinical situations (Witek-Janusek et al., 2007; Bellingrath et al., 2010; Nakata et al., 2011). Many humoral factors regulate the immune response, but $\mathrm{T}$ helper cells with their released cytokine are key factors in orchestrating the functions of the immune system (Smyth et al., 2005). One of the weak points in this study is that we could not study cytokine profile of the $\mathrm{T}$ helper cells to identify which subset is responsible for this elevation. However, many authors provided evidence that chronic stress can significantly alter the balance between Th1 and Th2 with strong deviation towards Th2 (Witek-Janusek et al., 2007; Gailen and Marshall, 2011) that favor the development of infections (Yang and Glaser, 2002), hypersensitivity (Stojanovich, 2010) and diabetes (Marshall, 2004). Höglund et al. (2006) reported an increase in the proportion of regulatory $T$ cells in the peripheral blood in both atopic and non atopic students in association with exams, a point that needs further investigations. 
Manar M. Ismail / American Journal of Immunology 2017, 13 (3): 186.193 DOI: 10.3844/ajisp.2017.186.193

Table 1. T cells, T helper and T cytotoxic percentages out of the total lymphocytes and the value of Th/Tc ratio.

\begin{tabular}{llll}
\hline & $\begin{array}{l}\text { Study group } \\
\text { (Samples at T1) }\end{array}$ & $\begin{array}{l}\text { Control group } \\
\text { (Samples atT2) }\end{array}$ & P value \\
\hline T cells & $70.5 \pm 4.6$ & $68.4 \pm 4.2$ & 0.096 \\
Mean \pm SD & $68.6(62.0-79.6)$ & $67.3(63.0-73.5)$ & $<0.001^{* *}$ \\
Median (Min-Max) & $43.6 \pm 5.2$ & $39.1 \pm 2.4$ & \\
T helper cells & $42.5(34.0-55.0)$ & $39.0(35.0-43.0)$ & $0.006^{*}$ \\
Mean \pm SD & $25.1 \pm 3.0$ & $27.0 \pm 2.6$ & $<0.001^{* *}$ \\
Median (Min-Max) & $25.3(20.0-32.2)$ & $26.5(23.0-32.2)$ & \\
Meantotoxic cells \pm SD & $1.7 \pm 0.3$ & $1.4 \pm 0.2$ & $1.4(1.2-1.7)$ \\
Median (Min-Max) & $1.8(1.1-2.5)$ & & \\
Th/Tc ratio & & & \\
Mean \pm SD & & &
\end{tabular}

*Significant

**Highly significant

Table 2. The percentages of natural killer (NK) cells and its two subsets

\begin{tabular}{llll}
\hline & $\begin{array}{l}\text { Study group } \\
\text { (Samples at T1) }\end{array}$ & $\begin{array}{l}\text { Control group } \\
\text { (Samples atT2) }\end{array}$ & $<$ Palue \\
\hline Natural Killer cells & & $10.2 \pm 3.1$ & $<0.001^{* *}$ \\
Mean \pm SD & $6.9 \pm 3.9$ & $10.0(6.0-16.0)$ & $<0.001^{* *}$ \\
Median (Min-Max) & $7.1(1.0-15.3)$ & $9.7 \pm 3.5$ & $<0.001$ \\
CD56 ${ }^{\text {bright }}$ NK cells & $59.4 \pm 18.2$ & $9.1(5.0-16.0)$ & \\
Mean \pm SD & $59.3(19.0-87.8)$ & $61.6 \pm 11.4$ & $60.0(46.0-81.0)$ \\
Median (Min-Max) & $19.5 \pm 16.8$ &
\end{tabular}

**Highly significant

${ }^{\wedge}$ Percentages of natural killer cells are out of the total lymphocytes while the percentages of bright and dim CD56 expression are out of the natural killer cells

Table 3. Comparison between mean values $\pm \mathrm{SD}$ of the studied parameters in relation to sleep disturbance

\begin{tabular}{|c|c|c|c|c|}
\hline & \multicolumn{2}{|l|}{ Study group } & \multirow[b]{2}{*}{ Control group $\mathrm{N}=27$} & \multirow[b]{2}{*}{$P$ value } \\
\hline & Sleep disturbance $\mathrm{N}=38$ & No sleep disturbance $\mathrm{N}=14$ & & \\
\hline T cells & $69.2 \pm 4.5 \mathrm{~b}$ & $69.8 \pm 4.9 \mathrm{~b}$ & $68.4 \pm 4.2 \mathrm{a}$ & 0.102 \\
\hline $\mathrm{T}$ helper cells & $43.4 \pm 5.5 \mathrm{~b}$ & $44.1 \pm 4.7 \mathrm{~b}$ & $39.1 \pm 2.4 \mathrm{a}$ & $<0.001 * *$ \\
\hline $\mathrm{T}$ cytotoxic cells & $25.0 \pm 2.8 \mathrm{~b}$ & $25.2 \pm 3.4 \mathrm{~b}$ & $27.0 \pm 2.6 \mathrm{a}$ & $0.023 *$ \\
\hline $\mathrm{CD} 4 / 8$ ratio & $1.7 \pm 0.3 \mathrm{~b}$ & $1.7 \pm 0.2 \mathrm{~b}$ & $1.4 \pm 0.2 \mathrm{a}$ & $<0.001 * *$ \\
\hline Natural Killer cells & $7.4 \pm 4.2 \mathrm{~b}$ & $5.6 \pm 2.8 \mathrm{~b}$ & $10.2 \pm 3.1 \mathrm{a}$ & $0.001 *$ \\
\hline Cd56 $6^{\text {bright }} \mathrm{NK}$ cells & $57.8 \pm 18.9 \mathrm{~b}$ & $63.5 \pm 16.2 \mathrm{~b}$ & $9.7 \pm 3.5 \mathrm{a}$ & $<0.001 * *$ \\
\hline CD56 ${ }^{\mathrm{dim}} \mathrm{NK}$ cells & $20.3 \pm 17.9 \mathrm{~b}$ & $17.4 \pm 13.5 \mathrm{~b}$ & $61.6 \pm 11.4 \mathrm{a}$ & $<0.001 * *$ \\
\hline
\end{tabular}

*Significant

**Highly significant

Groups sharing the same letter show no significance in-between

Table 4. Comparison between mean values $\pm \mathrm{SD}$ of the studied parameters in relation to infection

\begin{tabular}{|c|c|c|c|c|}
\hline & \multicolumn{2}{|l|}{ Study group } & \multirow[b]{2}{*}{ Control group $\mathrm{N}=27$} & \multirow[b]{2}{*}{$P$ value } \\
\hline & Infection $\mathrm{n}=18$ & No infection $\mathrm{N}=34$ & & \\
\hline T cells & $70.3 \pm 4.5 \mathrm{~b}$ & $68.9 \pm 4.6 \mathrm{~b}$ & $68.4 \pm 4.2 \mathrm{a}$ & 0.57 \\
\hline $\mathrm{T}$ helper cells & $45.5 \pm 5.4 \mathrm{~b}$ & $42.6 \pm 4.9 \mathrm{~b}$ & $39.1 \pm 2.4 \mathrm{a}$ & $<0.001 * *$ \\
\hline $\mathrm{T}$ cytotoxic cells & $24.6 \pm 2.5 \mathrm{~b}$ & $25.3 \pm 3.2 \mathrm{a} \& \mathrm{~b}$ & $27.0 \pm 2.6 \mathrm{a}$ & $0.016 *$ \\
\hline $\mathrm{CD} 4 / 8$ ratio & $1.8 \pm 0.2 \mathrm{~b}$ & $1.7 \pm 0.3 \mathrm{~b}$ & $1.4 \pm 0.2 \mathrm{a}$ & $<0.001 * *$ \\
\hline Natural Killer cells & $6.3 \pm 3.7 \mathrm{~b}$ & $8.2 \pm 4.1 \mathrm{a} \& \mathrm{~b}$ & $10.2 \pm 3.1 \mathrm{a}$ & $<0.001 * *$ \\
\hline CD56 ${ }^{\text {bright }} \mathrm{NK}$ cells & $59.5 \pm 22.9 \mathrm{~b}$ & $59.3 \pm 15.6 \mathrm{~b}$ & $9.7 \pm 3.5 \mathrm{a}$ & $<0.001 * *$ \\
\hline CD56 ${ }^{\mathrm{dim}} \mathrm{NK}$ cells & $18.7 \pm 18.3 \mathrm{~b}$ & $19.9 \pm 16.1 \mathrm{~b}$ & $61.6 \pm 11.4 \mathrm{a}$ & $<0.001 * *$ \\
\hline
\end{tabular}

*Significant

**Highly significant

Groups sharing the same letter show no significance in-between 
We detected a significant decrease in the count of the NK cells during stress. This result goes in hand with previous reports that described low count and or cytotoxicity of NK cells during stress (Bellingrath et al., 2010; Nakata et al., 2011; Duggal et al., 2015). Similarly, a decrease in NK cell number was reported in allergic students in context to exam stress (Kang et al., 1988; Höglund et al., 2006). Also the psychological stress that accompany the experience of diagnostic breast biopsy was accompanied by decrease in NK cell activity that lasts up to one month after the procedure (WitekJanusek et al., 2007) and similar results were detected in geriatric age group who are subjected to psychological stress after hip fracture (Duggal et al., 2005). On the same hand, some studies revealed the negative impact of job stress on NK activity (Boscoloa et al., 2016) and count (Bellingrath et al., 2010; Nakata, 2012) since work is a central part of life and job stress (e.g. high job demands and strain, low job control, job dissatisfaction, high effortreward imbalance, over commitment, unemployment etc..) affects both neuroendocrine and immune systems.

On the other hand, immunomodulation to acute psychological stress is associated with short-term selective up-regulation of NK cell activity (Breen et al., 2016) and number in the peripheral blood (Ho et al., 2010; Atanackovic et al., 2013). The increased number of NK cells is mostly related to peripheral migration of the cells rather than increased production in response to the sympatho-adrenergic response in acute stress that mediates increase in chemotaxis and adhesion molecules expression (Dragoş and Tănăsescu, 2010).

NK cells are key cells in the innate immune system; they act as front line fast defenders that kill virusinfected cells and cancer cells without prior sensitization (Matalka, 2003). The suppressor effect of chronic stress on the percentage of NK cells may be explained by different theories. First, stress may reduce the percent of proliferating thymocytes in the thymus gland where the NK cells develops (Kudryavtseva et al., 2011). Second, cytokine effect associated with shift of Th response towards Th2 during chronic stress. Th2 release IL4 and IL10 that cross regulate Th1 function leading to reduction of IFN $\gamma$ and IL-2 synthesis; both are up regulators to NK cells (Witek-Janusek et al., 2007). Third, mobilization of NK cells which is an immune response to physical and psychological stressors in humans (Schedlowski et al., 1993). Fourth, increased circulating level of immune suppressive glucocorticoids such as cortisol due to activation of the hypothalamuspituitary adrenal (HPA) axis during stress (Smith and Vale, 2006). Cortisol suppresses the activity of NK cells (Krukowski et al., 2010) mostly by epigenetic processes including deacetylation and transrepression of the immune response genes (Bush et al., 2012; Eddy, 2013).
Human NK cells constitute two distinct subsets identified by cell surface density of CD56. CD56 ${ }^{\mathrm{dim}} \mathrm{NK}$ cells forms the majority of NK cell population in the periphery and they are more cytotoxic against target cells (Jacobs et al., 2001). Also they express high levels of CD16 that enable them to perform antibody dependant cytotoxicity (Cooper et al., 2001). CD56 ${ }^{\text {bright }}$ population constitutes the majority in the secondary lymphoid tissue and is responsible for cytokine production upon stimulation (Cooper et al., 2001).

In the current work, there was a significant disturbance in the distribution of bright and dim CD56 expressing NK cells where there was a significant increase in the $\mathrm{CD} 56^{\text {bright }}$ and decrease in the $\mathrm{CD} 56^{\mathrm{dim}}$ NK cells during stress time point. Up to our knowledge we did not find a comparable study that described such disturbance in chronic psychosocial or mental stress. Most of the previous studies detected an increase in the level of CD56 ${ }^{\mathrm{dim}}$ NK cells with acute stress (Bosch et al., 2005) and others detect increased levels of both subsets with intensive physical training (Suzui et al., 2004). However most of the previous studies referred these changes to the differential expression of adhesion molecules and chemokine receptors that direct their migration to the lymphoid and non lymphoid tissue (Bush et al., 2012), a point that needs further investigation in chronic psychosocial stress.

Sleep disturbance was detected in $61.5 \%$ of the participant without significant difference from the group that did not report sleep disturbance which in hand with previous reports (Matzner et al., 2013; Irish et al., 2013). These data underscore the negative impact of poor sleep quality on the immune system.

In the current work, the group that developed infection during or shortly after the examination period showed a significant reduction in the number of $\mathrm{T}$ cytotoxic cells and NK compared to the group that did not report infection. This finding reflects a logical causal relationship, whenever the cellular response (Tc and NK cells) to infection decreases, infection will occurs. During chronic stress, the cortisol hormone with its famous suppressive effect on the immune system slowly increases over time and it will persist when compared to the effect of acute stress hormons; epinephrine and prostaglandine E2 (Gotlieb et al., 2015). This fact explains the increased susceptibility to infection during or shortly after chronic stress period. However, all the disturbed parameters appeared to normalize after sufficient rest period.

From the psychosocial point of view, not all stress has negative effect. When the body tolerates stress and uses it to overcome lethargy or enhance performance, the stress is positive, healthy and challenging and it force us to strength our adaptation mechanisms. Also, it warns us that a 
life style changes is needed if we are to maintain optimal health (Salleh 2008).

Finally, recreation activities are advised during or shortly after stress time like exam performance to avoid the distress that usually ends in sub-performance and bad academic achievement. Also to restore the normal physiology of our systems after long time exposure to the stress hormones.

\section{Conclusion}

In humans, naturalistic stress, as perceived during participation in academic exam, has the potential to negatively affect the immune system, but these changes are temporary and normality is regained after sufficient stress relieve measures. Replication in larger and more diverse sample populations with inclusion of male students for comparison is required, Also assessments of NK cell cytotoxicity, NK subsets and $\mathrm{T}$ helper cell subsets especially $\mathrm{T}$ regulatory cells are required for future studies.

\section{Acknowledgment}

The author appreciate the effort done by the Laboratory Medicine students, Faculty of Applied Medical Science, Umm Al Qura University namely; Suda Albeladi, Hanadi Bokhari, Rehab Alsowehri, Abrar Gandeel, Nada Gazaz and Somaya Dahlwi who shared in sample collection and preparation for flowcytometry analysis.

\section{Funding Information}

The author thanks Faculty of Applied Medical Science, Umm AL Qura University for providing the reagents needed for this study

\section{Ethics}

This article is original and contains unpublished material. The corresponding author confirms that no ethical issues involved.

\section{References}

Al-Qouzi, A., A. Al-Salamah, R. Al-Rasheed, A. AlMusalam and K. Al- Khairy et al., 2002. Immunophenotyping of Peripheral Blood Lymphocytes in Saudi Men. Clinical Diagnostic Laboratory Immunolgy, 9: 279-282.

Amr, M., A.H. El Gilany and A. El-Hawary, 2008. Does gender predict medical students' stress in mansoura, Egypt?. Medical Education Online, 13: 12.

DOI: $10.3402 /$ meo.v13i.4481
Atanackovic, D., U. Nowottne, E. Freier, C.S. Weber and S. Meyer et al., 2013. Acute psychological stress increases peripheral blood CD3+CD56+ natural killer $\mathrm{T}$ cells in healthy men: Possible implications for the development and treatment of allergic and autoimmune disorders. Stress, 16: 421-8. DOI: $10.3109 / 10253890.2013 .777702$

Basset, C., J. Holton, O'Mahony and I. Roitt.2003. Innate immunity and pathogen-host interaction. Vaccine, 21: S12-S23. DOI: $10.1016 / \mathrm{S} 0264-410 \mathrm{X}(03) 00195-6$

Bellingrath, S., N. Rohleder and B.M. Kudielka, 2010. Healthy working school teachers with high effortreward-imbalance and overcommitment show increased pro-inflammatory immune activity and a dampened innate immune defence. Brain Behavior Immunity, 24: 1332-1339. DOI: $10.1016 /$ j.bbi.2010.06.011

Bosch, J.A., G.G. Berntson, J.T. Cacioppo and P.T. Marucha, 2005. Differential mobilization of functionally distinct natural killer subsets during acute psychologic stress. Psychosomatic Medicine, 67: 366-375.

DOI: 10.1097/01.psy.0000160469.00312.8e

Boscoloa, P., L. Forcellaa, M. Realeb, G. Vianaleb and U. Battistic et al., 2016. Strain in different types of employment affects the immune response. Work, 41: 2950-2954. DOI: 10.3233/WOR-2012-0546-2950

Breen, M.S., N. Beliakova-Bethell, L.R. Mujica-Parodi, J.M. Carlson and W.Y. Ensign et al., 2016. Acute psychological stress induces short-term variable immune response. Brain Behavior Immunity, 53: 172-182. DOI: 10.1016/j.bbi.2015.10.008

Bush, K.A., K. Krukowski, J.L. Eddy, L.W. Janusek and H.L. Mathews, 2012. Glucocorticoid receptor mediated suppression of natural killer cell activity: Identification of associated deacetylase and corepressor molecules. Cell Immunology, 275: 8089. DOI: 10.1016/j.cellimm.2012.02.014

Castrillón, E., K. Sarsosa, F. Moreno and S. Moreno, 2015. Academic stress and immunological manifestations: Evidence of psycho-neuroendocrineimmunology (abstract). Salut Sci. Spiritus, 1: 16-28.

Cooper, M.A., T.A. Fehniger and M.A. Caligiuri, 2001. The biology of human natural killer-cell subsets. Trends Immunology, 22: 633-640. DOI: 10.1016/S1471-4906(01)02060-9

Dragoş, D. and M.D. Tănăsescu, 2010. The effect of stress on the defense systems. Journal of Medicine and Life, 3: 10-18.

Duggal, N.A., J. Upton, A.C. Phillips, P. Peter Hampson and J.M. Lord.2015. NK cell immunesenescence is increased by psychological but not physical stress in older adults associated with raised cortisol and reduced perforin expression. AGE, 37: 48. DOI 10.1007/s11357-015-9748-2 
Eddy, J.L., 2013. Characterization of chronic glucocorticoid exposure on natural killer cell function: A model for stress induced alterations on the epigenetic landscape. Dissertations.

Fefelova, E.V., P.P. Tereshkov, O.K. Plotnikova, A.N. Stafeev and A.V. Semenov et al., 2015. Influence of exam stress on the development of endothelial dysfunction and the formation of platelet-leukocyte coagregates (Abstract). Ross Fiziol Zh Im I M Sechenova, 101: 134-9.

Gailen, D. and J.r. Marshall, 2011. The adverse effects of psychological stress on immunoregulatory balance: Applications to human inflammatory diseases. Immunology Allergy Clinic North America, 31: 133-140. DOI: 10.1016/j.iac.2010.09.013

Gotlieb, N., E. Rosenne, P. Matzner, L. Shaashua and L. Sorski et al., 2015.The misleading nature of in vitro and ex vivo findings in studying the impact of stress hormones on NK cell cytotoxicity. Brain Behavior Immunity, 45: 277-286.

DOI: $10.1016 /$ j.bbi.2014.12.020

Gruzelier, J., F. Smith, A. Nagy and D. Henderson, 2001. Cellular and humoral immunity, mood and exam stress: The influences of self-hypnosis and personality predictors. International Journal of Psychophysiology, 42: 55-71.DOI: 10.1016/S0167-8760(01)00136-2

Ho, R.C., L.F. Neo, A.N. Chua, A.A. Cheak and A. Mak, 2010. Research on psychoneuroimmunology: Does stress influence immunity and cause coronary artery disease?. Annals Academy Medicine, 39: 191-6.

Höglund, C.O., J. Axén, C. Kemi, S. Jernelöv and J. Grunewald et al., 2006. Changes in immune regulation in response to examination stress in atopic and healthy individuals. Clinical Experimental Allergy, 36: 982-92. DOI: $10.1111 / \mathrm{j} .1365-2222.2006 .02529 . \mathrm{x}$

Irish, L.A., A.L. Dougall, D.L. Delahanty and M.H. Hall, 2013. The impact of sleep complaints on physical health and immune outcomes in rescue workers: A 1-year prospective study. Psychosomatic Medicine, 75: 196-201.DOI: 10.1097/PSY.0b013e31827d85ab

Jacobs, R., G. Hintzen, A. Kemper, K. Beul and S. Kempf et al., 2001. CD56 ${ }^{\text {bright }}$ NK cells differ in their KIR repertoire and cytotoxic features from CD56 ${ }^{\text {dim }}$ NK cells. European Journal of Immunology, 31: 3121-3126.

Kang, D.H. and C. Fox, 2001. Th1 and Th2 cytokine responses to academic stress. Research Nursing Health, 24: 245-57. DOI: 10.1002/nur.1027

Kang, D.H., C.L. Coe, J. Karaszewski and D.O. McCarthy, 1988. Relationship of social support to stress responses and immune function in healthy and asthmatic adolescents. Research Nursing Health, 21: 117-28.
Kiecolt-Glaser, J.K., T.J. Loving, J.R. Stowell, W.B. Malarkey and S. Lemeshow et al., 2005. Hostile marital interactions, proinflammatory cytokine production and wound healing. Archive General Psychiatry, 62: 1377-1384.

DOI: $10.1001 /$ archpsyc.62.12.1377

Krukowski, K., J. Eddy, K.L. Kosik, T. Konley and L.W. Janusek et al., 2010. Glucocorticoid dysregulation of natural killer cell function through epigenetic modification. Brain Behavior Immunity, 25: 239249. DOI: 10.1016/j.bbi. 2010.07.244

Kudryavtseva, N.N., A.V. Shurlygina, E.V. Melnikova, M.V. Tenditnik and N.P. Bondar et al., 2011. Cell cycle arrest in the thymus and spleen in male mice under conditions of chronic social defeat stress: Effects of diazepam. Bulletin of Experimental Biology and Medicine, 151: 411-415. DOI: $10.1007 / \mathrm{s} 10517-011-1343-7$

Lee, J. and A.V. Graham, 2001. Students' perception of medical school stress and their evaluation of wellness elective. Medical Education, 35: 652-659. DOI: $10.1046 /$ j.1365-2923.2001.00956.x

Marazziti, D., F. Ambrogi, M. Abelli, E. Di Nasso and M. Catena et al., 2007. Lymphocyte subsets, cardiovascular measures and anxiety state before and after a professional examination. Stress, 10: 93-9.

DOI: 10.1080/10253890601170563

Marshall, G.D. and S.K. Agarwal, 2000. Stress, immune regulation and immunity: Applications for asthma. Allergy Asthma Proceeding, 21: 241-6. DOI: $10.2500 / 108854100778248917$

Marshall, G.D., 2004. Neuroendocrine mechanisms of immune dysregulation: Applications to allergy and asthma. Annals Allergy, Asthma Immunology, 932: 11-17. DOI: 10.1016/S1081-1206(10)61482-2

Matalka, K.Z., 2003. Neuroendocrine and cytokinesinduced responses to minutes, hours and days of mental stress. Neuroendocrinology Letters, 24: 283-292.

Matzner, P., O. Hazut, R. Naim, L. Shaashua and L. Sorski et al., 2013. Resilience of the immune system in healthy young students to 30-hour sleep deprivation with psychological stress. Neuroimmunomodulation, 20: 194-204.

DOI: $10.1159 / 000348698$

Naito, A., T.M. Laidlaw, D.C. Henderson, L. Farahani and P. Dwivedi et al., 2003. The impact of selfhypnosis and Johrei on lymphocyte subpopulations at exam time: A controlled study. Brain Research Bulletin, 62: 241-53.

DOI: $10.1016 /$ j.brainresbull.2003.09.014

Nakata, A., 2012. Psychosocial job stress and immunity: A systematic review. Methods Molecular Biology, 934: 39-75. DOI: 10.1007/978-1-62703-071-7_3 
Nakata, A., M. Takahashi and M. Irie, 2011. Effort reward imbalance, over commitment and cellular immune measures among white-collar employees. Biological Psychology, 88: 270-279. DOI: 10.1016/j.biopsycho.2011.08.012

Nemeroff, C., 2013. Psychoneuroimmunoendocrinology: The biological basis of mind-body physiology and pathophysiology. Depression Anxiety, 30: 285-292. DOI: $10.1002 /$ da. 22110

Peters, E.M.J., Y. Müller, W. Snaga, H. Fliege and A. Reißhauer et al., 2017. Hair and stress: A pilot study of hair and cytokine balance alteration in healthy young women under major exam stress. PLoS One, 12: e0175904. DOI: 10.1371/journal.pone.0175904

Phillips, A.C., D. Carroll, V.E. Burns, C. Ring and J. Macleod et al., 2006. Bereavement and marriage are associated with antibody response to influenza vaccination in the elderly. Brain Behavior Immunity, 20: 279-289. DOI: $10.1016 /$ j.bbi.2005.08.003

Pittman, Q., 2011. A neuro-endocrine-immune symphony. Journal of Neuroendocrinology, 23: 1296-1303.DOI: 10.1111/j.1365-2826.2011.02176.x

Salleh, M.R., 2008. Life event, stress and illness. Malaysian Journal of Medical Sciene., 15: 9-18.

Schedlowski, M., R. Jacobs, J. Alker, F. Prohl and G. Stratmann et al., 1993. Psychophysiological, neuroendocrine and cellular immune reactions under psychological stress. Neuropsychobiology, 28: 87-90. DOI: $10.1159 / 000119006$

Segerstrom, S.C. and G.E. Miller, 2004. Psychological stress and the human immune system: A metaanalytic study of 30 years of inquiry. Psychological Bulletin, 130: 601-631. DOI: $10.1037 / 0033-2909.130 .4 .601$

Shaikh, B.T., A. Kahloon, M. Kazmi, H. Khalid and K. Nawaz et al., 2004. Students, stress and coping strategies: A case of Pakistani medical school. Education Health, 17: 346 -353.

DOI: $10.1080 / 13576280400002585$
Smith, S.M. and W.W.Vale, 2006. The role of the hypothalamicpituitary- adrenal axis in neuroendocrine responses to stress. Dialogues Clinical Neuroscience, 8: 383-395.

Smyth, M.J., E. Cretney, J.M. Kelly, J.A. Westwood and S.E. Street et al., 2005. Activation of NK cell cytotoxicity. Molecular Immunology, 42: 501-510. DOI: 10.1016/j.molimm.2004.07.034

Stojanovich, L., 2010. Stress and autoimmunity. Autoimmunne Rev., 9: 271-276. DOI: 10.1016/j.autrev.2009.11.014

Suzui, M., T. Kawai, H. Kimura, K. Takeda and H. Yagita et al., 2004. Natural killer cell lytic activity and $\mathrm{CD} 56^{\mathrm{dim}}$ and $\mathrm{CD} 56^{\text {bright }}$ cell distributions during and after intensive training. Journal of Applied Physiology, 96: 2167-2173.

DOI: 10.1152/japplphysiol.00513.200

Witek-Janusek, L., S. Gabram and H.L. Mathews, 2007. Psychological stress, reduced NK cell activity and cytokine dysregulation in women experiencing diagnostic breast biopsy. Psychoneuroendocrinology, 32: 22-35. DOI: 10.1016/j.psyneuen.2006.09.011

Yang, E.V. and R. Glaser, 2002. Stress-associated immunomodulation and its implications for responses to vaccination. Expert Review of Vaccines, 1: 453-459. DOI: $10.1586 / 14760584.1 .4 .453$

Zorrilla, E.P., L. Luborsky, J.R. McKay, R. Rosenthal and A. Houldin et al., 2001. The relationship of depression and stressors to immunological assays: A meta-analytic review. Brain Behavior Immunity, 15: 199-226. DOI: 10.1006/brbi.2000.0597 